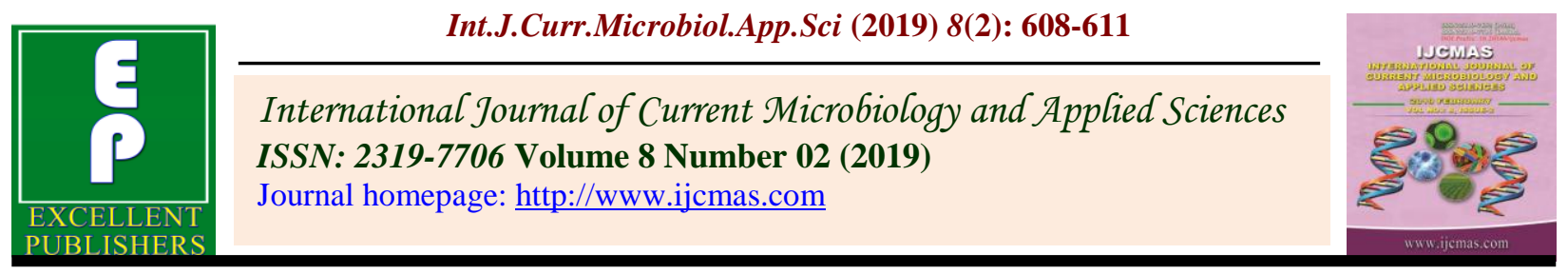

Original Research Article

https://doi.org/10.20546/ijcmas.2019.802.069

\title{
Entrepreneurial Behavior of Rural Dairy Farmers
}

\author{
Chaitra L. Patil* and A.K. Singh \\ Department of Extension Education, Institute of Agricultural Sciences, \\ Banaras Hindu University Varanasi, India \\ *Corresponding author
}

A B S T R A C T

\section{Keywords}

Entrepreneurship,

Dairy farmer,

Entrepreneurial

behaviour, Milch

animal

Article Info

Accepted:

07 January 2019

Available Online:

10 February 2019
The present study was conducted in Kashi Vidyapeeth block of Varanasi district of Uttar Pradesh during 2017-18. From the three villages chosen from Kashi Vidyapeeth block, total 120 respondents practicing dairy and possessing at least one milch animal such as cow/buffalo were selected purposively to find the entrepreneurial behaviour of dairy farmers. The data was collected by personal interview with the help of structured interview schedule. The study revealed that majority of the dairy farmers found to have medium level of entrepreneurial behaviour followed by high and low level of entrepreneurial behaviour.

\section{Introduction}

The importance of dairying in our country hardly needs emphasizing. The vast resources (more than 50 per cent of the world's buffalos and 20 per cent of its cattle) of livestock in the country play an important role in the national economy as well as in the socioeconomic development of millions of rural households. Dairy enterprise could play a more constructive role in promoting rural welfare and reducing poverty by generating employment at farm level is increasingly being recognized. A sustainable and financially viable dairy farming, which will generate income and self-employment through entrepreneurship, is the need of the day (Shah et al., 2003). In the present era, it is being realized that entrepreneurship contributes to development of a country in several ways, viz. assembling and harnessing the various inputs, bearing the risks, innovating and imitating the techniques of production to reduce the cost and increase its quality and quantity, expanding the horizons of the market, and coordinating and managing the manufacturing unit at various levels. In fact, the rapid economic development of a country crucially depends upon the number of abilities of entrepreneurs. In this context, entrepreneur is one of the most important inputs for development of dairy enterprise 
which may prove phenomenal for economic development of farming community. Keeping the above facts in view, the present study was carried out with following objective: To assess the level of entrepreneurship of dairy farmers.

\section{Materials and Methods}

The study was conducted during 2017-18 in Varanasi district Uttar Pradesh. From the Varanasi district Kashi Vidyapeeth block was selected purposively. From Kashi Vidyapeeth block three villages having more number of farmers practicing dairying are selected purposively. From each selected village 40 farmers having at least one milch animal were selected randomly constituting total of 120 respondents as sample size and data were collected by personal interview method with the help of structured interview schedule. Statistical tools such as frequency, percentage, mean and standard deviation were used to analyse the collected data. The term entrepreneurial behaviour has been operationalized as a composite skill, the resultant of mix of many qualities and traits. The entrepreneurial behaviour of the respondents was studied using the dimensions viz., innovativeness, achievement motivation, decision making ability, risk - orientation, coordination ability and planning ability. Based on entrepreneurial behaviour score, the respondents were classified into three groups' viz., low, medium and high on the basis of Mean \pm SD.

\section{Results and Discussion}

\section{Entrepreneurial behaviour of dairy farmers}

The perusal of data in Table 1 shows the distribution of dairy farmers according to their entrepreneurial behaviour. It is apparent from the data that majority 65.00 per cent of dairy farmers were found to have medium level of entrepreneurial behaviour followed by high 18.33 per cent and low 16.66 per cent. The logical reasons of medium followed by, high entrepreneurial behaviour might be due to their sound financial condition, higher land holding, higher education level and higher scientific orientation. However, all the major eleven components of entrepreneurial behaviour of dairy farmers together reflect their medium entrepreneurial behaviour. These findings are in accordance with the findings of Bhagyalaxmi et al., (2003) and Suresh (2004). However, the dairy farmers should have high level of entrepreneurship. Hence, special consideration is required to develop the entrepreneurship in dairy farmers because dairy enterprise is one of the promising sectors of entrepreneurship development in India.

\section{Components of Entrepreneurial behaviour}

The entrepreneurial behaviour of dairy farmers comprised six components, such as, innovativeness, achievement motivation, decision making ability, risk orientation, coordinating ability and planning ability. Data have been furnished in Table 2. The profile of dairy farmers on entrepreneurial characteristics is given below.

\section{Innovativeness}

It is observed from Table 2 that 47.50 per cent of dairy farmers belonged to medium category of innovativeness, followed by 37.50 per cent of respondents had low level of and only 15 per cent of dairy farmers had high level of innovativeness. These results are in accordance with the findings of Bhagyalaxmi et al., (2003) and Suresh (2004).

\section{Achievement motivation}

It is evident from the Table 2 that more than half 55.84 per cent of the dairy farmers had medium level of achievement motivation, 
whereas 23.33 per cent dairy farmers belonged to high achievement motivation category, followed by 20.83 per cent low achievement motivation category. Similar results have been reported by Vijaykumar (2001) and Suresh (2004).

Table.1 Entrepreneurial behaviour of dairy farmers $(\mathrm{N}=120)$

\begin{tabular}{|c|c|c|}
\hline Category & Frequency & Per cent \\
\hline Low & 20 & 16.66 \\
\hline Medium & 78 & 65.00 \\
\hline High & 22 & 18.33 \\
\hline
\end{tabular}

Table.2 Distribution of dairy farmers based on components of entrepreneurial behaviour of dairy farmers $(\mathrm{N}=120)$

\begin{tabular}{|c|c|c|c|c|}
\hline Component & Frequency & Per cent & Mean & SD \\
\hline \multicolumn{5}{|c|}{ Innovativeness } \\
\hline Low & 45 & 37.50 & \multirow[t]{3}{*}{3.21} & \multirow[t]{3}{*}{1.10} \\
\hline Medium & 57 & 47.50 & & \\
\hline High & 18 & 15.00 & & \\
\hline \multicolumn{5}{|c|}{ Achievement motivation } \\
\hline Low & 25 & 20.83 & \multirow[t]{3}{*}{2.78} & \multirow[t]{3}{*}{1.50} \\
\hline Medium & 67 & 55.84 & & \\
\hline High & 28 & 23.33 & & \\
\hline \multicolumn{5}{|c|}{ Decision making ability } \\
\hline Low & 33 & 27.50 & \multirow[t]{3}{*}{8.29} & \multirow[t]{3}{*}{1.10} \\
\hline Medium & 61 & 50.83 & & \\
\hline High & 26 & 21.67 & & \\
\hline \multicolumn{5}{|c|}{ Risk orientation } \\
\hline Low & 38 & 31.67 & \multirow[t]{3}{*}{5.94} & \multirow[t]{3}{*}{2.86} \\
\hline Medium & 51 & 42.50 & & \\
\hline High & 31 & 25.83 & & \\
\hline \multicolumn{5}{|c|}{ Coordinating ability } \\
\hline Low & 25 & 20.83 & \multirow[t]{3}{*}{4.62} & \multirow[t]{3}{*}{1.36} \\
\hline Medium & 69 & 57.50 & & \\
\hline High & 26 & 21.67 & & \\
\hline \multicolumn{5}{|c|}{ Planning ability } \\
\hline Low & 37 & 30.83 & \multirow[t]{3}{*}{3.37} & \multirow[t]{3}{*}{1.04} \\
\hline Medium & 69 & 57.50 & & \\
\hline High & 14 & 11.67 & & \\
\hline
\end{tabular}

\section{Decision making ability}

It could be inferred from Table 2 that majority 50.83 per cent of dairy farmers were having medium level of decision making ability, whereas 27.50 per cent of dairy farmers were having low level of decision making ability and 21.67 per cent of dairy farmers were 
having high level of decision making ability. Similar trend have been reported by Vijaykumar (2001) and Suresh (2004).

\section{Risk orientation}

The data furnished in Table 2 revealed that majority 42.50 per cent of dairy farmers had medium level of risk orientation followed by 31.67 per cent of dairy per cent of dairy farmers had low level of risk orientation, whereas 25.83 per cent of dairy farmers had high level of risk orientation. These findings are accordance with the findings of Bhagyalaxmi et al., (2003) and Suresh (2004).

\section{Coordinating ability}

It is apparent from Table 2 that majority $\mathbf{5 7 . 5 0}$ per cent of the dairy farmers had medium coordinating ability followed by 21.67 per cent and 20.83 per cent of dairy farmers having high and medium co-ordinating ability of dairy activities, respectively. The result obtained in the present study is in line with the findings of Vijaykumar (2001).

\section{Planning ability}

It is clear from the Table 2 that majority 57.50 per cent of dairy farmers had medium level of planning ability with 30.83 per cent possessing low and only 11.67 per cent of respondents having high planning ability respectively. Only few dairy farmers possess high planning ability this might be due to the fact that most of dairy farmers did not give importance to the activities, which would help them in future.
In conclusion, the study revealed that, majority of dairy farmers had medium level entrepreneurial behaviour which is an apparent indication of the permissiveness of dairy growers. Efforts for increased awareness and knowledge in dairy production techniques through various innovative extension methods exclusively designed for the target group is urgently needed. This will help them to acquire day to day technical developments and the impact of adoption of those scientific practices on their dairy business and livelihood.

\section{References}

Bhagyalaxmi, K., Gopalakrishna Rao, V. and Sudarshanreddy, M., 2003, Profile of the rural women micro-entrepreneurs. Journal of Research, Acharya N.G. Ranga Agric Univ., Hyderabad 31 (4): 51-54.

Saha, B., Jancy Gupta and Sabyarachi Das 2003, Knowledge of clean milk production practices among dairy farmers of West Bengal. Indian Journal of Extension Education., 39 (3\&4): 230233.

Suresh., 2004, Entrepreneurial behaviour of milk producers in Chittoor district of Andhra Pradesh - A critical study. $M$. V. Sc. Thesis, Acharya N. G. Ranga Agricultural University, Hyderabad.

Vijaykumar, K., 2001, Entrepreneurship behaviour of floriculture farmers in Ranga Reddy district of Andhra Pradesh. M. Sc.(Agri.) Thesis, Acharya N.G. Ranga Agriculture University., Hyderabad.

\section{How to cite this article:}

Chaitra L. Patil and Singh, A.K. 2019. Entrepreneurial Behavior of Rural Dairy Farmers. Int.J.Curr.Microbiol.App.Sci. 8(02): 608-611. doi: https://doi.org/10.20546/ijcmas.2019.802.069 